Egyptian Journal of Aquatic Biology \& Fisheries

Zoology Department, Faculty of Science,

Ain Shams University, Cairo, Egypt.

ISSN $1110-6131$

Vol. 22(4): 263- 271 (2018)

ejabf.journals.ekb.eg

\title{
Quality Evaluation of Three Types of Fish Pastirma during Frozen Storage
}

\author{
Mohamed Abou-Taleb; Abdelrahman S. Talab; Mohamed A. Ibrahim; Fify R. Anees; \\ Maha E. Genina; Mostafa M. Mahmoud and Shimaa M. Abou-Taleb. \\ Fish Processing and Technology Lab., Fisheries Division, National Institute of Oceanography \\ and Fisheries, Cairo, Egypt.
}

\begin{abstract}
ARTICLE INFO
Article History:

Accepted: Sept. 28, 2018

Available online: Oct. 2018

Keywords:

Fish pastirma

Quality criteria

Sensory evaluation

Frozen storage

Quality evaluation
\end{abstract}

Received: Aug. 29, 2018

\begin{abstract}
The main objective of this investigation was to evaluate the quality of three types of fish pastirma prepared from common carp (Cyprinus carpio L.), kawakawa (Euthynnus affinis) and little tuna (Euthynnus alletteratus) during frozen storage at $-18^{\circ} \mathrm{C}$ for three months. Physiochemical, microbiological and sensory properties of fish pastirma were determined. At zero time the results showed that, the values of $\mathrm{pH}$, TVBN, TMA, TBA and TBC ranged between (4.82-5.42), (10.47-43.89 mg/100g), (2.56-10.70 $\mathrm{mg} / 100 \mathrm{~g}), \quad(0.017-0.111 \mathrm{mg} \quad \mathrm{MDA} / \mathrm{kg})$ and (1.23-1.77 $\log \mathrm{cfu} / \mathrm{g})$; respectively. Also, results indicated that the values of $\mathrm{pH}$, TVBN, TMA and TBA parameter were increased during storage period at $-18^{\circ} \mathrm{C}$ and all samples did not exceed the maximum permissible levels as determined by the Egyptian Standard Specification for both freshwater and marine fish. Staphylococcus aureus, E.coli, total coliform were not detected during storage of three types of fish pastirma. In addition, total bacterial count was increased at the first month of storage then decreased till the end of storage but not exceed the MPL reported by ESS. Sensory evaluation did not change significantly $(p>0.05)$ in both three types of fish pastirma. The study concluded that the effect of frozen storage at $-18^{\circ} \mathrm{C}$ on fish pastirma quality properties varied between fish species and depended on the functional properties of fish muscles and all samples gain high organoleptic acceptance as an alternative and cheap product compared to the meat product.
\end{abstract}

\section{INTRODUCTION}

Seafood is one of the most important food commodities consumed worldwide as a high-quality, healthy, and safe food. However, it can be fast spoiled by bacteria and food-borne pathogens, resulting in spoilage and disease outbreaks with potential hazard effects on human health (Cruz et al., 2015). So that, fish freezing as a highly effective, non-destructive and cost-efficient method of food preservation is the most widely used method for delay oxidation and proteolytic activity to extend the shelflife and protect the quality properties of fish products (Śmiecińska et al., 2015).

Fish pastirma is dry-cured product with special taste and palatability opportunities which processed through approximately one month by curing, drying, pressing and coating with garlic, paprika, red pepper and water containing paste and again drying (Kok et al., 2009 and Kaban, 2009). 
There are very limited numbers of publications regarding to fish pastirma. Yapar, (1992) determined the quality parameters (physical, chemical, microbiological and sensory attributes) of fish pastirma. Arslan, et al., (1997a) produced vacuumed fish pastrami from Cyprinus carpio, stored at $4 \pm 1{ }^{\circ} \mathrm{C}$ for 120 days. Arslan, et al., (1997b) determined the microbiological and chemical properties of vacuumed and un-vacuumed mirror carp (Cyprinus carpio L.) pastirma stored at market temperature $\left(20^{\circ} \mathrm{C}\right)$ for 120 days. Arslan and Kok, (2001) studied the microbiological and chemical changes in sliced and vacuumed Barbus esocinus pastirma during storage at $4 \pm 1^{\circ} \mathrm{C}$. Kok and Arslan, (2003) investigated the effect of storage time in cumin paste for 12,24 and $48 \mathrm{~h}$ on the microbiological, chemical and sensorial quality of vacuum packed barbel (Barbus esocinus) fish pastirma during storage at $20^{\circ} \mathrm{C}$ for 90 day. Kok et al., (2009) studied sensory, chemical and microbiological changes of catfish (Silurus glanis L.) pastirma stored at $20^{\circ} \mathrm{C}$ for three months. Mahmoud et al., (2016) determined physicochemical, microbiological and organoleptic analysis of common carp (Cyprinus carpio) fish pasitrma stored at $25 \pm 2{ }^{\circ} \mathrm{C}$ for 15 days. Therefore, the aim of this study was focus on production and evaluation the quality of three types of fish pastirma during frozen storage at $-18^{\circ} \mathrm{C}$ for three months.

\section{MATERIALS AND METHODS}

\section{Materials}

About $200 \mathrm{~kg}$ of common carp (Cyprinus carpio L.), Kawakawa (Euthynnus affinis) and Little Tuna (Euthynnus alletteratus) fresh fish samples were collected from Alexandria fish market, and transported in icebox to Fish Processing and Technology Laboratory, Fish Research Station, El-Kanater El-Khiria, National Institute of Oceanography and Fisheries within 3 hours. Fenugreek flour, salt and spices (red pepper and cumin) were obtained from Cairo local market.

\section{Methods}

\section{Processing of fish pastirma}

Fish samples prepared under hygienic condition, all fish samples were rewashed, beheaded, eviscerated, skin removed and filleted. Fish pastirma were processed as follows: Fish fillets were rewashed, drained, salted as dry salting for 6 hours $\left(20 \mathrm{~g}\right.$ salt/100 $\mathrm{g}$ fillet), washing to remove of salt, $1^{\text {st }}$ drying at room temperature by hanging fillet, pressing by mechanical compressor, $2^{\text {nd }}$ drying at room temperature, coated with ç emen: (50\% fenugreek flour, 35\% garlic and $15 \%$ red pepper and sufficient amount of water) as given by Tekinşen and Doğruer (2000). The coated fillet left until the coated layer complete drying, samples were hanged and left for drying at ambient temperature $\left(25^{\circ} \mathrm{C} \pm 3\right)$ for 5-7 days until coated layer was dried and had about $3 \mathrm{~mm}$ thickness. Pastirma samples were packed in open polyethylene bags, which divided for storing at $-18^{\circ} \mathrm{C}$ and subjected to organoleptic analysis as fried, physicochemical and microbiological analysis (Fig. 1).

\section{Analytical methods Physicochemical analysis}

Moisture, crude protein, fat, ash contents and $\mathrm{pH}$ value were carried out according to the methods recommended by the AOAC (2000). Total volatile basic nitrogen (TVB-N) contents were determined according to the method described by Pearson (1976). While, the thiobarbituric acid (TBA) value was measured according to the method described by Tarladgis et al. (1960). 


\section{Microbiological analysis}

Ten gram of each sample were aseptically taken into a sterile homogenizer flask (Homogenizer type MPW-302, Poland), to which $90 \mathrm{ml}$ of sterile $(0.1 \%)$ peptone water diluted were added and homogenized for 2 minutes at $800 \mathrm{rpm}$ to provide a homogenate of $10^{-1}$ dilution. The homogenate was thoroughly mixed. One $\mathrm{ml}$ of homogenate was transferred into a sterile test tube containing $9 \mathrm{ml}$ of $0.1 \%$ peptone water, then ten - fold serial dilution were prepared up to $10^{-6}$ (Anon, 1978). Total bacterial count, total coliforms count, Escherishia coli and staphylococcus aureus were determined according to APHA (1992).
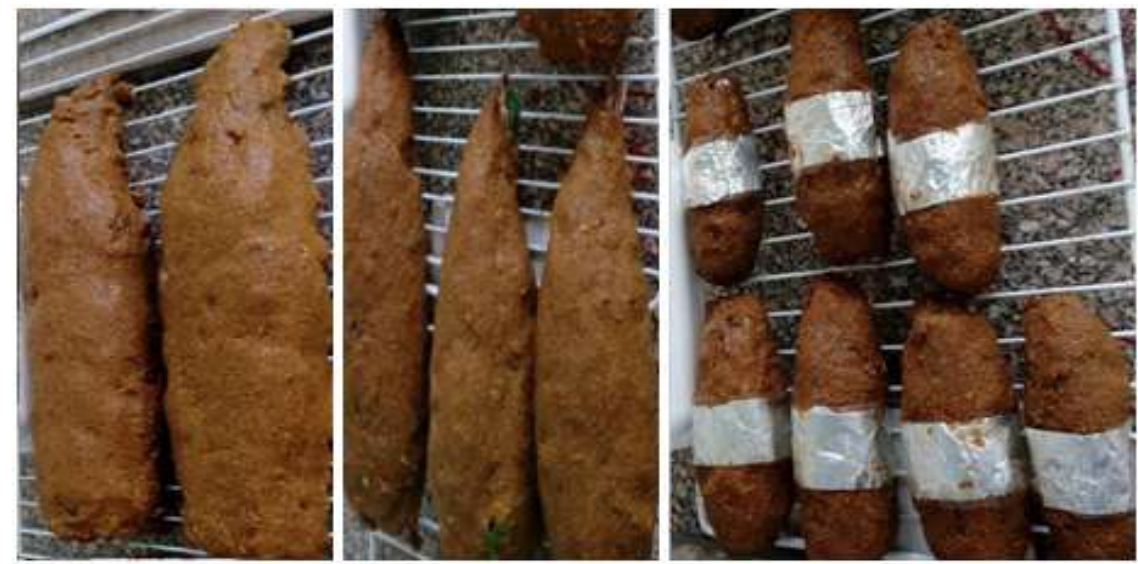

Fig. 1: Common carp, kawakawa and little tuna fish pastirma samples.

\section{Sensory analysis}

The sensory characteristics of fried fish pastirma was carried out according to Amerine et al., (1965); it was done in terms of color, tenderness, taste, flavor and overall acceptability. Fish pastirma was evaluated by 10 panelists from National Institute of Oceanography and Fisheries, El-Kanater El-Khiria. A 9 point hedonic scale was employed in this sensory analysis. Samples evaluated as fresh processed pastirma and during storage at $-18^{\circ} \mathrm{C}$ for three months. The frying process was done in vegetable oil at $170^{\circ} \mathrm{C}$ for $1 \mathrm{~min}$ for all samples by using electric fryer.

\section{Statistical analysis}

All measurements were performed in triplicate and values expressed as the mean \pm SD. Statistical analyses were performed using SPSS 18.00 for Windows. Analysis of variance (ANOVA) was used and statistical significance was set at $\mathrm{p}<$ 0.05 to detect the significant effect between means during storage periods according to (Snedecor and Cochran, 1980).

\section{RESULTS AND DISCUSSTION}

\section{Chemical composition of fish pastirma}

The moisture, protein, lipids and ash of common carp, kawakawa and little tuna fish pastirma at zero time were $(50.48,50.16,60.82),(38.16,42.04,32.53),(5.07$, $3.40,3.39)$ and $(3.51,3.21,1.28)$; respectively (Table 1). Kok et al. (2009) found that, moisture, protein, fat and ash contents of catfish pastirma at zero time were (35.66, 39.60, 11.36 and 12.96), respectively, while Mahmoud et al. (2016) found that, moisture, protein, fat, ash and carbohydrates contents of common carp fish pastirma at zero time were $51.80,21.27,13.38,8.54$ and $1.01 \%$; respectively. During frozen storage moisture contents of common carp, kawakawa and little tuna fish 
pastirma decreased from 50.48, 50.36 and $62.82 \%$ at zero time to $45.93,44.23$ and $60.34 \%$ at the end of storage period; respectively. Protein and lipid contents of common carp, kawakawa and little tuna fish pastirma were increased during the first month of frozen storage then decreased until the end of frozen storage. Ash contents of common carp, kawakawa and little tuna fish pastirma increased during frozen storage from $3.51,3.21$ and $1.28 \%$ at zero time to $8.01,7.70$ and $3.82 \%$ at the end of storage period; respectively (Fig. 2).

Table 1: Chemical composition of fresh fish pastirma samples.

\begin{tabular}{|l|c|c|c|}
\hline Constitutes & Common carp & Kawakawa & Little Tuna \\
\hline Moisture (\%) & $50.48 \pm 0.09$ & $50.16 \pm 0.32$ & $60.82 \pm 0.13$ \\
\hline Protein (\%) & $38.16 \pm 0.18$ & $42.04 \pm 0.33$ & $32.53 \pm 0.41$ \\
\hline Lipids (\%) & $5.07 \pm 0.49$ & $3.40 \pm 0.16$ & $3.39 \pm 0.63$ \\
\hline Ash (\%) & $3.51 \pm 0.78$ & $3.21 \pm 0.27$ & $1.28 \pm 0.46$ \\
\hline
\end{tabular}

Data are presented as means \pm standard deviation (SD)
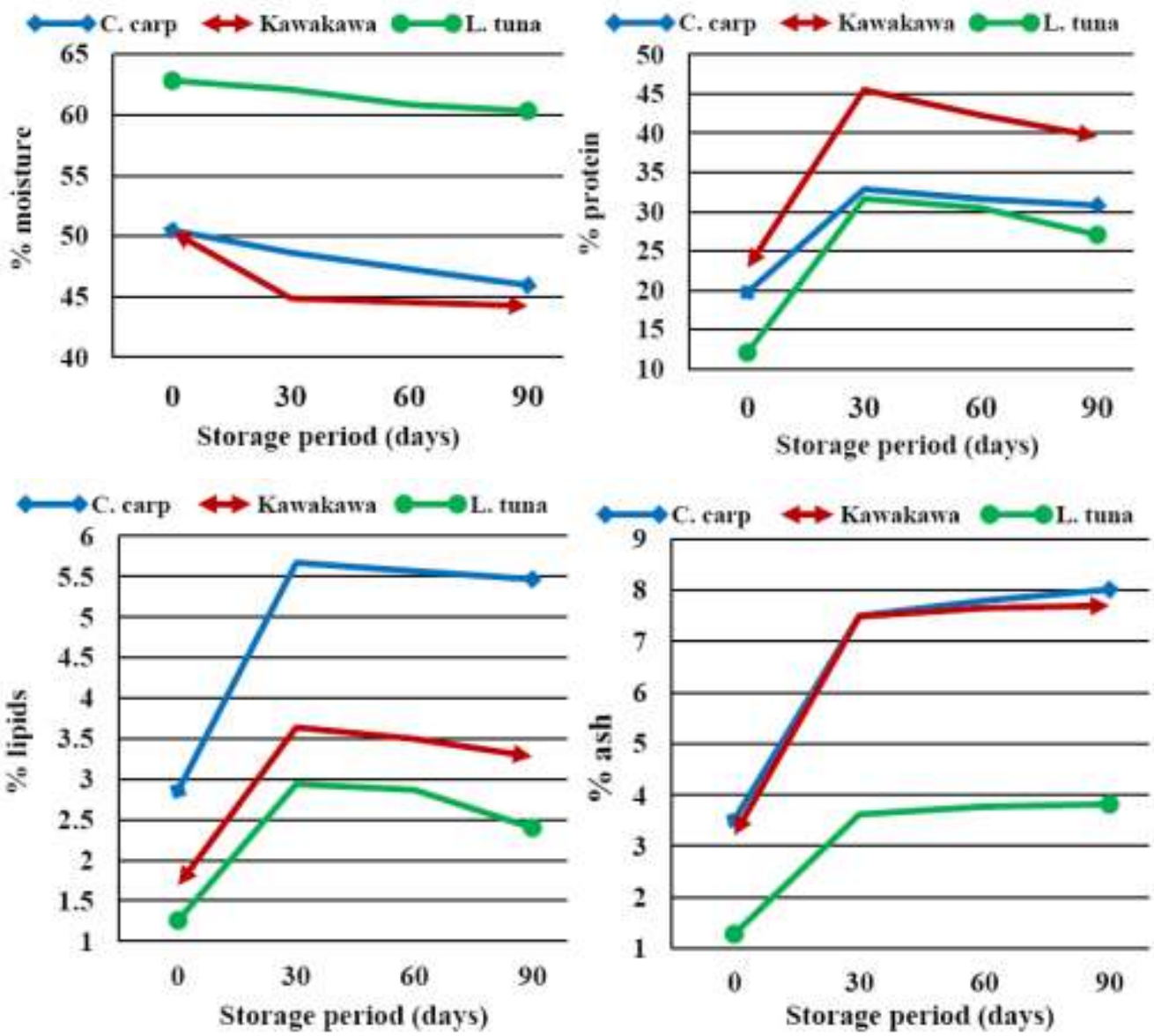

Fig. 2: Effect of frozen storage on chemical composition (\%, on w/w) of fish pastirma samples.

The obtained results agree with those reported by Mahmoud et al.(2016) who found that, moisture content of common carp fish pastirma was decreased from 51.80 at zero time to $40.73 \%$ at the end of storage at $25 \pm 2{ }^{\circ} \mathrm{C}$. While, protein, lipid and Ash contents of common carp fish pastirma were increased from $21.27,13.38$ and $8.54 \%$ at zero time to 27.50 , and $13.86 \%$ at the end of storage at $25 \pm 2^{\circ} \mathrm{C}$; respectively. On the other hand, Kok et al., (2009) found fluctuation in moisture, protein, lipids and Ash contents during 90 day of storage at $20^{\circ} \mathrm{C}$. 


\section{Physicochemical analysis of fish pastirma}

The $\mathrm{pH}, \mathrm{TVBN}, \mathrm{TMA}$ and TBA values of common carp, kawakawa and little tuna fish pastirma at zero time were $(4.82,5.38,5.42),(10.47,37.17,43.89$ $\mathrm{mg} / 100 \mathrm{~g}),(2.56,9.14,10.70 \mathrm{mg} / 100 \mathrm{~g})$ and $(0.017,0.111,0.030 \mathrm{mg} \mathrm{MDA} / \mathrm{kg})$; respectively (Table 2). Kok et al.(2009) found that, $\mathrm{pH}$ value of catfish pastirma at zero time was (5.72), while Mahmoud et al. (2016) found that, $\mathrm{pH}$ value, TVBN and TBA of common carp fish pastirma at zero time were 6.4, 15.65 and 0.05; respectively. The $\mathrm{pH}, \mathrm{TVBN}, \mathrm{TMA}$ and TBA values of common carp, kawakawa and little tuna fish pastirma increased during frozen storage tile reached to $(7.88,7.94$, 8.13), (13.36, 43.96, $49.91 \mathrm{mg} / 100 \mathrm{~g}),(5.41,13.35,14.26 \mathrm{mg} / 100 \mathrm{~g})$ and $(0.402$, 2.340, $2.360 \mathrm{mg} \mathrm{MDA} / \mathrm{kg}$ ); respectively at the end of frozen storage (Figure, 3). On the other hand, Kok, et al., (2009) found that $\mathrm{pH}$ value was decreased from 5.72 at zero time to 5.44 at the end of storage period at $20^{\circ} \mathrm{C}$ for 90 day. Mahmoud, et al., (2016) found that, $\mathrm{pH}$ value of common carp fish pastirma was decreased from 6.51 at zero time to 5.80 at the end of storage at $25 \pm 2^{\circ} \mathrm{C}$. Also found that, TVBN content of common carp fish pastirma was increased from 15.65 at zero time to $34.80 \%$ at the end of storage at $25 \pm 2^{\circ} \mathrm{C}$. While, TBA values of common carp fish pastirma were fluctuated during storage at $25 \pm 2^{\circ} \mathrm{C}$.
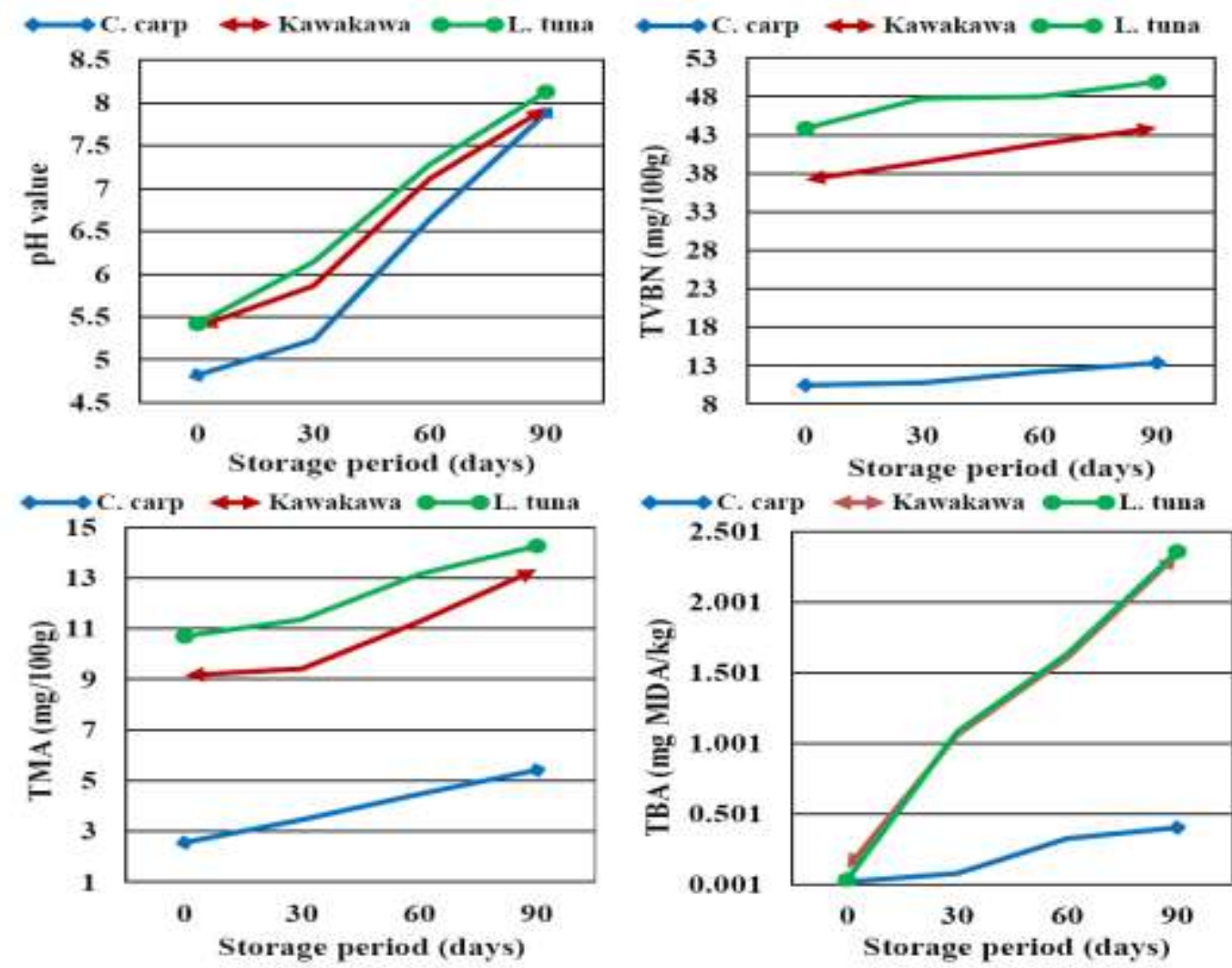

Fig. 3: Effect of frozen storage on physicochemical (on w/w) properties of fish pastirma samples.

\section{Microbiological analysis of fish pastirma}

Staphylococcus aureus, E. coli, total coliform not detected at zero time and during storage of three types of fish pastirma until the end of storage. In addition, total bacterial count (TBC) of common carp, kawakawa and little tuna fish pastirma at zero time were 1.23, 0.85 and $1.77 \mathrm{log} \mathrm{cfu} / \mathrm{g}$; respectively (Table 2). TBC of common carp and little tuna fish pastirma increased from 1.23 and $1.77 \log \mathrm{cfu} / \mathrm{g}$ at the first month of frozen storage to 1.26 and $1.78 \mathrm{log} \mathrm{cfu} / \mathrm{g}$ then decreased to 1.11 and $1.76 \log \mathrm{cfu} / \mathrm{g}$ at the end of storage. While, TBC of kawakawa fish pastirma was 
decreased from $0.85 \mathrm{log} \mathrm{cfu} / \mathrm{g}$ at zero time to $0.30 \mathrm{log} \mathrm{cfu} / \mathrm{g}$ at the end of frozen storage; respectively (Figure 4). In addition, total bacterial count was increased during storage period but not exceed the MPL reported by ESS. Mahmoud et al. (2016) who found that, TBC of common carp fish pastirma at zero time was $9 \times 10^{3}$ $\mathrm{cfu} / \mathrm{g}$.

Table 2: Physicochemical and microbiological quality criteria of fresh fish pastirma samples

\begin{tabular}{|l|c|c|c|}
\hline \multicolumn{1}{|c|}{ Parameters } & Common carp & Kawakawa & Little Tuna \\
\hline pH value & $4.82 \pm 0.03$ & $5.38 \pm 0.03$ & $5.42 \pm 0.06$ \\
\hline TVBN (mg/100g) & $10.47 \pm 0.47$ & $37.17 \pm 0.28$ & $43.89 \pm 0.17$ \\
\hline TMA (mg/100g) & $2.56 \pm 0.16$ & $9.14 \pm 0.11$ & $10.70 \pm 0.14$ \\
\hline TBA (mg MDA/Kg) & $0.017 \pm 0.003$ & $0.111 \pm 0.009$ & $0.03 \pm 0.011$ \\
\hline TBC (log cfu/g) & 1.23 & 0.85 & 1.77 \\
\hline Staphylococcus aureus & $\mathrm{nd}$ & $\mathrm{nd}$ & $\mathrm{nd}$ \\
\hline E.coli & $\mathrm{nd}$ & $\mathrm{nd}$ & $\mathrm{nd}$ \\
\hline Total coliform & $\mathrm{nd}$ & $\mathrm{nd}$ & $\mathrm{nd}$ \\
\hline
\end{tabular}

Data are presented as means \pm standard deviation (SD)

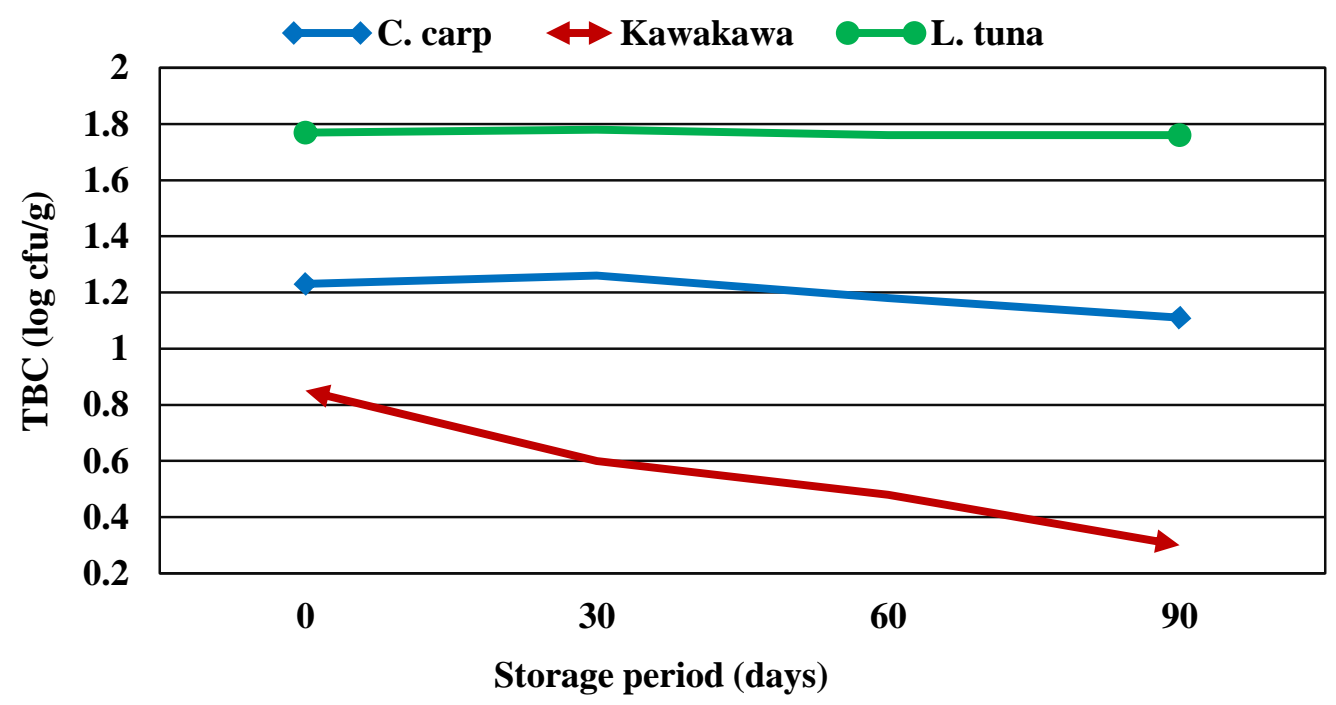

Fig. 4: Effect of frozen storage on TBC (log cfu/g) of fish pastirma samples.

\section{Sensory characteristics of fish pastirma}

Sensory evaluation was carried out after frying process of fish pastirma. The mean values of appearance, flavor, taste, tenderness, juiciness and overall acceptability of different types of fish pastirma indicated that common carp fish pastirma was the best type > kawakawa fish pastirma > little tuna fish pastirma (Table, 3). Figure (5) showed the changes of appearance, flavor, taste, tenderness, juiciness and overall acceptability of fish pastirma processed from common carp, kawakawa and little tuna during storage at $-18^{\circ} \mathrm{C}$ for 90 days.

Table 3: Sensory evaluation of fish pastirma samples

\begin{tabular}{|l|c|c|c|}
\hline \multicolumn{1}{|c|}{ Parameters } & Common carp & Kawakawa & Little Tuna \\
\hline Appearance & $9 \pm 1.14$ & $8 \pm 0.89$ & $7 \pm 0.73$ \\
\hline Flavor & $9 \pm 0.75$ & $8 \pm 0.80$ & $7 \pm 1.03$ \\
\hline Taste & $9 \pm 1.16$ & $8 \pm 0.99$ & $7 \pm 1.12$ \\
\hline Tenderness & $9 \pm 1.17$ & $8 \pm 1.41$ & $7 \pm 0.94$ \\
\hline Juiciness & $9 \pm 1.29$ & $8 \pm 1.06$ & $7 \pm 0.88$ \\
\hline Overall acceptability & $9 \pm 0.94$ & $8 \pm 0.83$ & $7 \pm 1.03$ \\
\hline
\end{tabular}

Data are presented as means \pm standard deviation (SD). 

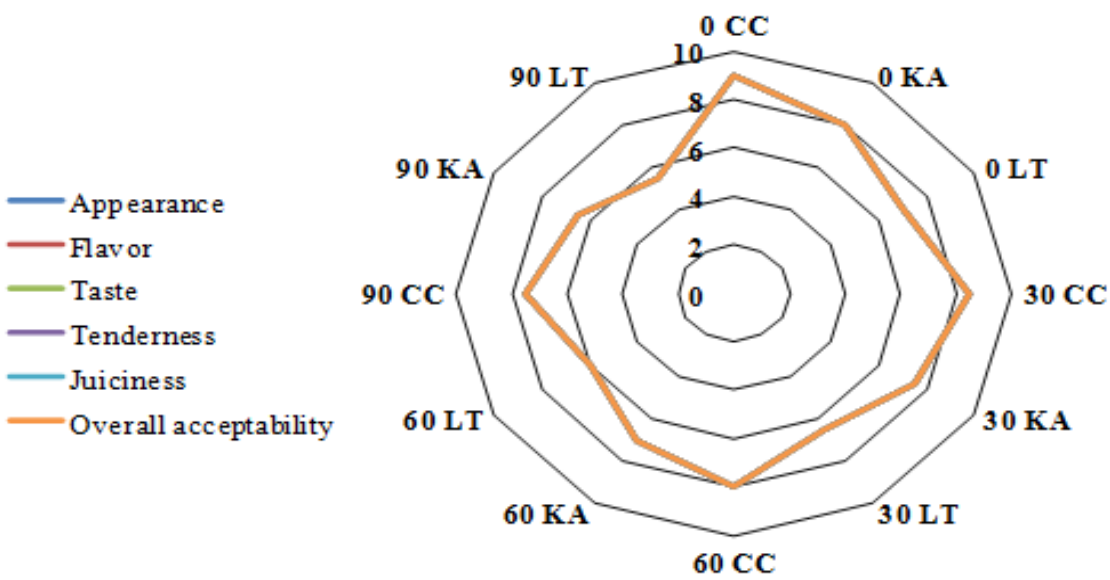

Fig. 5: Effect of frozen storage on sensory evaluation of fish pastirma samples. CC: Common Carp; KA: Kawakawa and LT: Little Tuna.

The obtained results explained the same trend of sensory parameters during frozen storage and pastirma processed from common carp was the best type followed by kawakawa and little tuna fish.

\section{CONCLUSION}

The study concluded that the fish pastirma produced from common carp, kawakawa and little tuna fish gain high organoleptic acceptance as an alternative and cheap product compared to meat and the common carp fish pastirma the best type followed by kawakawa and little tuna. Effect of frozen storage at $-18^{\circ} \mathrm{C}$ for three months on the fish pastirma quality properties varied between fish species and depended on the functional properties of fish muscles.

\section{REFERENCES}

Amerine, M. A.; Pangborn, R. M. and Rocssler, E. B. (1965). Principles of Sensory Evalution of Foods. 349p, Academic press, New York.

Anon (1978). Microorganisms in foods. 1. Their significance and methods of enumeration, $2^{\text {nd }}$ edn. (Ed. International Commission on Microbiological Specifications for Foods). Toronto, University of Toronto Press.

AOAC (2000). Official Methods of Analysis of the Association of Analytical Chemists. 18th Ed., Washington, D.C., USA.

APHA (1992). American Publish Health Association Compendium of Methods for the Microbiological Examination of Foods. Washington D.C, USA.

Arslan, A. and Kö k, F. (2001). Investigation of microbiological and chemical changes in sliced and vacuumed Barbus esocinus pastrami during storage time at $+4^{\circ} \mathrm{C}$. Firat Univ. Turk. J. Health Sci., 15: 337-344.

Arslan, A.; Ḉ elik, C.; Gö nülala, Z.; Ates, G.; Kö k, F. and Kaya, A. (1997a). Analysis of microbiological and chemical qualities of vacuumed and unvacuumed mirror carp (Cyprinus carpino L.) pastrami. Turk. J. Vet. Anim. Sci., 21(1): 23-29.

Arslan, A.; Gö nülala, Z. and Ç elik, C. (1997b). Effect of storage time on mirror carp (Cyprinus carpino L.) pastrami stored in market temperature. Turk. J. Vet. Anim. Sci., 21(3): 215-220. 
Cruz, R.; Cunha, S. C. and Casal, S. (2015). Brominated flame retardants and seafood safety: a review. Environ. Int., 77:116-131.

Kaban, G. (2009). Changes in the composition of volatile compounds and in microbiological and physicochemical parameters during pastırma processing. Meat Sci., 82: 17-23.

Kok, F. and Arslan, A. (2003). The effect of different storage time periods in cumin paste on the quality of barbus esocinus pastirma. Turk J Vet Anim Sci; 27: 181188.

Kö k, F.; Goksoy, O. E. and Gonulalan, Z. (2009). The Microbiological, chemical and sensory features of vacuumed-packed weels catfish (Silurus glanis L.) pastrami stored under ambient conditions $\left(20^{\circ} \mathrm{C}\right)$. J. Animal and Veterinary Advances, 8 (4):817-824.

Mahmoud, M. M.; Khallaf, M. F.; Nessrien, M.N. Yasin and Abou-Taleb, M. (2016). Quality Characteristics of Common Carp Fish Pastirma. Annals of Agric. Sci., Moshtohor, 54 (1): 95-104.

Pearson, D. (1976). The Chemical Analysis of Food .Chem. Pub. Comp. Inc., New York.

Śmiecińska, K.; Hnatyk, N.; Daszkiewicz, T.; Kubiak, D. and Matusevičius, P. (2015). The effect of frozen storage on the quality of vacuum-packaged turkey meat. Veterinarija ir Zootechnika (Vet Med Zoot). T., 71 (93): 61-66.

Snedecor, G.W. and Cochran, W.G. (1980). Statistical Methods. $7^{\text {th }}$ Edition, Iowa State University Press, Ames.

Tarladgis, B. G.; Watts, B. M.; Younathan, M. T. and Dugan, Jr. L. (1960). A distillation method for the quantitative determination of malonaldehyde in rancid foods. J. Am. Oil Chem. Soc., 37: 44-48.

Tekinşen, O. C. and Dogruer, Y. (2000). Pastirma all about. Selcuk University Basimevi, Konya, Turkey, p. p: 124. ISBN: 97-95678-2-2. CF: Kö k, F.; Goksoy, O. E. and Gonulalan, Z. (2009). The Microbiological, chemical and sensory features of vacuumed-packed weels catfish (Silurus glanis L.) pastrami stored under ambient conditions $\left(20^{\circ} \mathrm{C}\right)$. Journal of Animal and Veterinary Advances, 8 (4): 817-824.

Yapar, A. (1992). Production of fish pastrami and determination of quality parameters. Doktora Tezi. Biyoteknoloji Anabilim Dali. Firat University, Fen Bil., Elazig, Turkey. CF: Kö k, F.; Goksoy, O. E. and Gonulalan, Z. (2009). The Microbiological, chemical and sensory features of vacuumed-packed weels catfish (Silurus glanis L.) pastrami stored under ambient conditions $\left(20^{\circ} \mathrm{C}\right)$. Journal of Animal and Veterinary Advances, 8 (4): 817-824. 


\title{
ARABIC SUMMARY
}

\section{تقييم جودة ثلاثة أنواع من بسطرمة السمك أثناء التخزين بالتجميا}

\author{
محمد أبوطالب، عبدالرحمن سعيد تطب، محمد عبدالهادى إبراهيم، فيفى راغب أنيس، مها إسماعيل جنينة،

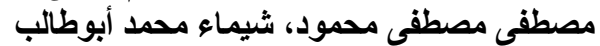 \\ معمل تكنولوجيا تصنيع الأسماك، شعبة المصايد، المعهد ألقومى لعلوم البحار و المصايد، القاهرة، مصر
}

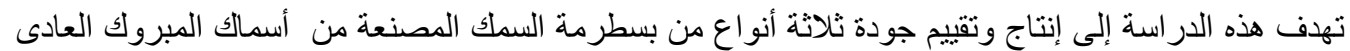

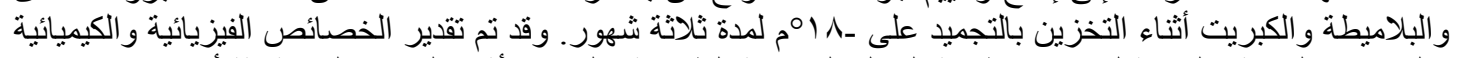

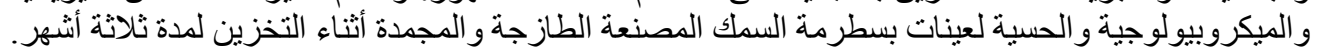

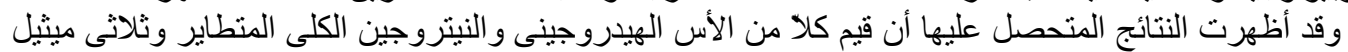

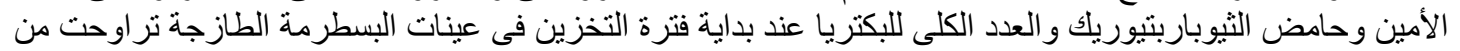

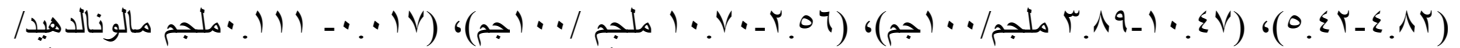

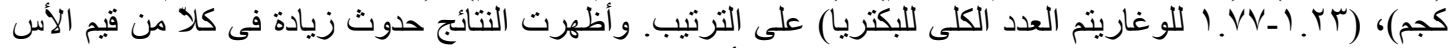

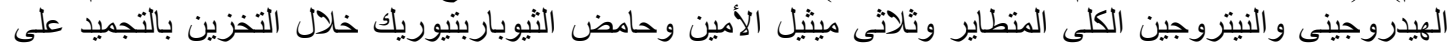

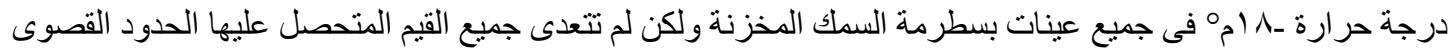

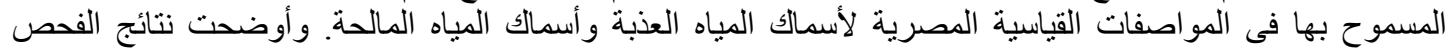

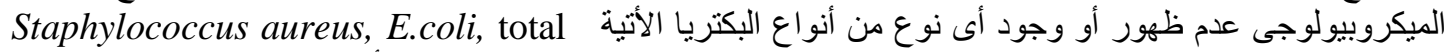
coliform

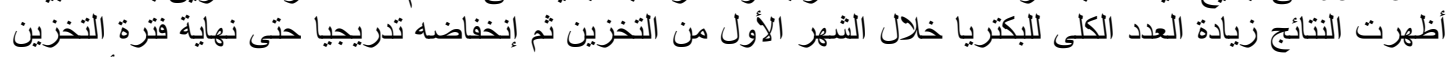

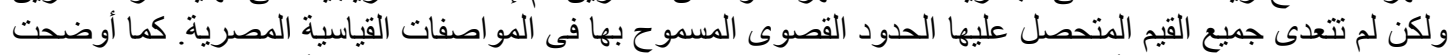

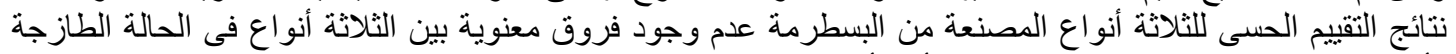

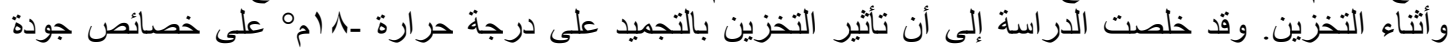

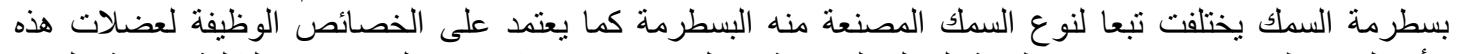
الأسماك وحظيت جميع عينات بسطرمة السمك المصنعة بقبول حسي مرتفع كمنتج بديل منخفض التبل التكلفة مقارنة بالمنتج

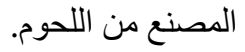

